\title{
Adenocarcinoma following urinary diversion
}

\author{
Peter Yicum Jian, MD; ${ }^{*}$ Guilherme Godoy, MD; ${ }^{*}$ Michael Coburn, MD; Garrett Lynch, MD; ${ }_{i}^{*}$ Jae Y. Ro, MD; ${ }^{*}$ \\ Qihui "Jim" Zhai, MD;
}

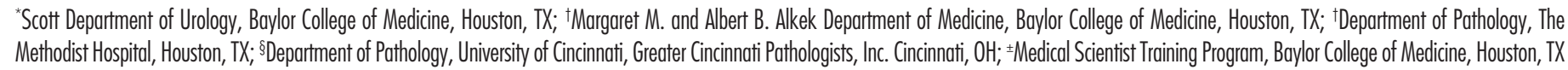

Cite as: Can Urol Assoc J 2012;6(2):e77-80. http://dx.doi.org/10.5489/cuaj.11065

\section{Abstract}

The use of bowel segments in urinary diversions has been associated with an increased risk of neoplasia. This report describes three cases of intestinal adenocarcinoma following urinary diversion. In the first case, a 73-year-old woman developed moderately-differentiated colonic adenocarcinoma in her Indiana pouch 10.5 years after cystectomy. The second case involved a 77-year-old man with well-differentiated adenocarcinoma in his Indiana pouch 9 years after radical cystoprostatectomy and en bloc urethrectomy. The third case involved a 38-year-old man with moderately-differentiated adenocarcinoma arising in his ileal conduit 33 years after the creation of the conduit. These cases highlight the diagnostic signs of adenocarcinoma arising in urinary diversions and emphasize the importance of lifelong surveillance in these patients.

\section{Introduction}

Exposure of intestinal mucosa to urine has been associated with an increased risk of tumorigenesis. ${ }^{1}$ Although the pathogenesis of these tumours has not been well-established, many possible explanations exist. First, in patients with ureterosigmoidostomy, the blending of fecal and urinary materials is thought to increase the production of nitrosamines at the site of the uretero-colonic anastamosis. ${ }^{2}$ Second, in the absence of fecal and urinary blending, chronic inflammation, irritation, presence of stones and elevation of a variety of substances have been implicated in carcinogenesis within the intestinal segment. ${ }^{1}$ The carcinogenic substances currently being investigated include nitrosamine, reactive oxygen species, epidermal growth factor, transforming growth factor, cyclo-oxygenase, mucin and ornithine transcarbamylase. ${ }^{1}$ Many of these substances have also been suggested as potential causes of adenocarcinoma in not only Indiana pouches and ileal conduits, but also in neobladders. In the absence of mixing of the urinary and fecal streams, there does not appear to be any increased risk per se in a urinary diversion beyond that inherent in the bowel segment in a non-diverted patient. Third, de novo adenocarcinoma may develop in any bowel segment, including the portion used in urinary diversions. ${ }^{3}$ Thus, the origin of these tumours is likely to be multifactorial. The following uncommon presentations of adenocarcinoma following urinary diversion surgery emphasize the diverse circumstances in which these malignancies can develop.

\section{Case 1}

A 73-year-old female with a history of recurrent non-muscle invasive urothelial carcinoma of the bladder came to urology clinic. Her chief complaint was hematuria 10.5 years after radical cystectomy, extended lymph node dissection and continent urinary diversion with an Indiana pouch. Final pathology of the cystectomy showed a pTaG2_urothelial carcinoma of the bladder and carcinoma in situ. She had been in continuous follow-up postoperatively without evidence of recurrence. Magnetic resonance imaging (MRI) of the abdomen demonstrated a solid 2.5-cm mass localized in the posterior-inferior wall inside the Indiana pouch (Fig. 1, panel A). Endoscopy of the pouch revealed a sessile mucinous mass, and biopsy of the lesion was consistent with adenocarcinoma of the colon. Colonoscopy did not show any primary lesions in the large bowel, and an extensive metastatic workup was negative. The Indiana pouch was resected en bloc with the mesentery which was equivalent to a right hemicolectomy, which is standard of care. The urinary diversion was replaced by an ileal conduit.

The pouchectomy specimen contained a $3.5 \times 2.5 \mathrm{~cm}$, firm, off-white, polypoid lesion in a segment of large bowel (Fig. 1, panel B). The lesion was located $2.5 \mathrm{~cm}$ and $3 \mathrm{~cm}$ from each of the inner ureteral orifices and $4 \mathrm{~cm}$ from the ileocecal valve. Histological examination of the tumour revealed moderately-differentiated colonic adenocarcinoma 


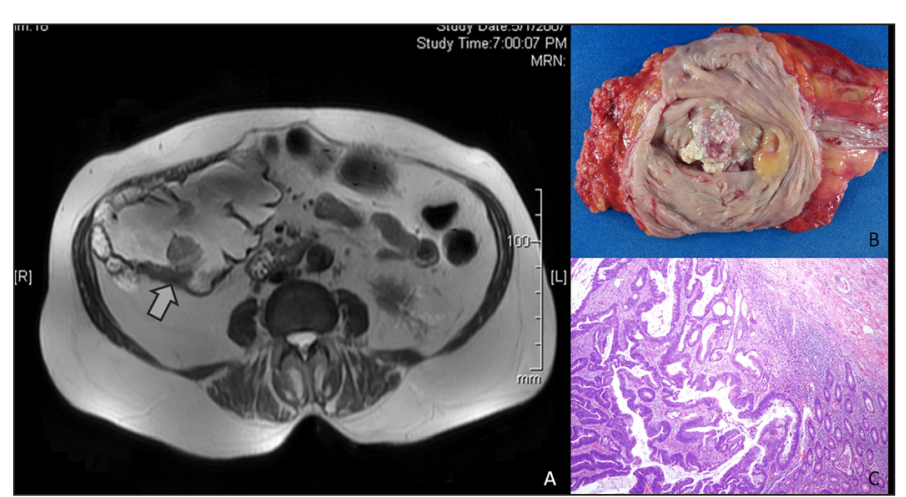

Fig. 1. A. Post-gadolinium $T 2$ weighted magnetic resonance imaging of the abdomen in case 1 demonstrates a solid $2.5 \mathrm{~cm}$ mass in the posterior-inferior wall inside the Indiana pouch as indicated by the arrow. B. The resected Indiana pouch contains a $3.5 \times 2.5 \mathrm{~cm}$, firm, off-white, polypoid lesion in a segment of the large bowel. C. Histological examination of the tumor reveals moderately differentiated colonic adenocarcinoma that invades into the submucosa. (Hemotoxin \& Eosin, low power magnification).

invading into the submucosa (Fig. 1, panel C). No lymphovascular invasion was detected. Nineteen benign lymph nodes were identified, and resection margins were free of tumour. The final stage of the adenocarcinoma was T1, N0, M0. The patient recovered uneventfully from surgery, and is alive and free of disease 3 years after surgery.

\section{Case 2}

A 77-year-old male with a history of recurrent non-muscle invasive urothelial carcinoma of the bladder came to the urology clinic. His chief complaint was hematuria 9 years after treatment with radical cystoprostatectomy, en bloc ure-

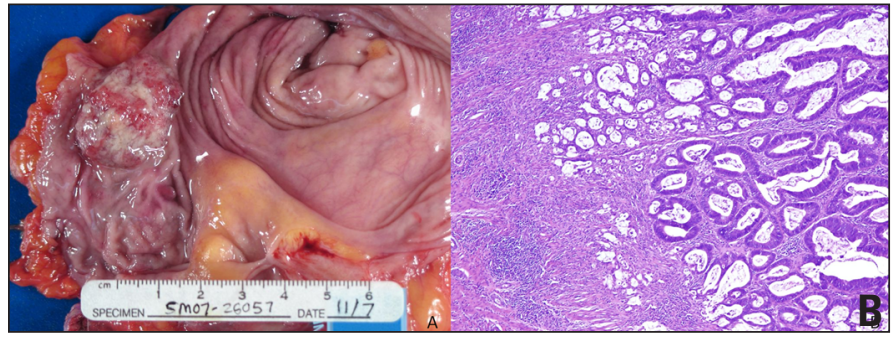

Fig. 2. A. The resected Indiana pouch in case 2 contains a $3.0 \times 2.3 \mathrm{~cm}$, firm, fungating mass in a segment of the large bowel. B. Histological examination of the tumour under high power magnification reveals well differentiated colonic adenocarcinoma that invades into the superficial muscularis propria. (Hemotoxin \& Eosin, low power magnification).

threctomy, extended lymph node dissection and continent urinary diversion with an Indiana pouch. His final pathology showed carcinoma in situ of the bladder and prostatic urethra. He had been in continuous follow-up postoperatively without evidence of recurrence. Endoscopy of the pouch revealed a sessile mass, and biopsy of the lesion was consistent with adenocarcinoma of the colon. The Indiana pouch was resected, and the urinary diversion was replaced by an ileal conduit, similar to the first case.

The pouchectomy specimen contained a $3.0 \times 2.3 \mathrm{~cm}$, firm, fungating mass in the large bowel segment (Fig. 2, panel A). This mass was located $3.1 \mathrm{~cm}$ from the right ureter, $5.5 \mathrm{~cm}$ from the left ureter and $12 \mathrm{~cm}$ from the ileocecal valve. Histological examination of the tumour revealed a well-differentiated colonic adenocarcinoma invading into the superficial muscularis propria (Fig. 2, panel B). No lymphovascular invasion was detected. Ten benign lymph nodes were identified, and resection margins were free of tumour.

\begin{tabular}{|c|c|c|c|c|c|c|c|}
\hline Author (year) & Age & Sex & $\begin{array}{l}\text { Time between } \\
\text { creation of the Indiana } \\
\text { pouch and detection } \\
\text { of tumour (years) }\end{array}$ & $\begin{array}{l}\text { Indication } \\
\text { for Indiana } \\
\text { Pouch }\end{array}$ & $\begin{array}{l}\text { Family history of } \\
\text { colorectal CA }\end{array}$ & $\begin{array}{l}\text { Presence } \\
\text { of stones } \\
\text { in the } \\
\text { pouch }\end{array}$ & Signs and symptoms \\
\hline Lisle et al. $(2000)^{15}$ & 76 & M & 6 & $\begin{array}{l}\text { Bladder } \\
\text { cancer }\end{array}$ & $\begin{array}{l}\text { Brother \& daughter } \\
\text { with colon cancer }\end{array}$ & No & Gross hematuria \\
\hline $\begin{array}{l}\text { Gazzaniga et al. } \\
(2000)^{19}\end{array}$ & 73 & M & 2 & $\begin{array}{l}\text { Bladder } \\
\text { cancer }\end{array}$ & No & No & $\begin{array}{l}\text { Difficulty passing a catheter, } \\
\text { pouch distention }\end{array}$ \\
\hline $\begin{array}{l}\text { L'Esperance et al. } \\
(2001)^{16}\end{array}$ & 72 & $\mathrm{~F}$ & 6 & $\begin{array}{l}\text { Bladder } \\
\text { cancer }\end{array}$ & N/A & No & $\begin{array}{l}\text { Gross hematuria, malodorous, } \\
\text { particulate discharge }\end{array}$ \\
\hline Uesugl et al. $(2002)^{14}$ & 71 & M & 10 & $\begin{array}{l}\text { Bladder } \\
\text { cancer }\end{array}$ & No & No & Gross hematuria \\
\hline Komai et al. $(2005)^{17}$ & 63 & $\mathrm{~F}$ & 6 & $\begin{array}{l}\text { Bladder } \\
\text { cancer }\end{array}$ & No & Yes & $\begin{array}{l}\text { Difficulty with catheterization, } \\
\text { overflow incontinence }\end{array}$ \\
\hline Ho et al. $(2007)^{18}$ & 66 & $\mathrm{~F}$ & 16 & $\begin{array}{l}\text { Cervical } \\
\text { cancer }\end{array}$ & N/A & No & Gross hematuria \\
\hline Ryochi et al. $(2007)^{3}$ & 76 & $\mathrm{~F}$ & 15 & $\begin{array}{l}\text { Rectal } \\
\text { cancer }\end{array}$ & $\begin{array}{l}\text { Past history of rectal } \\
\text { cancer }\end{array}$ & Yes & $\begin{array}{c}\text { Presence of urinary stone in } \\
\text { the pouch }\end{array}$ \\
\hline Current Case 2 & 73 & $\mathrm{~F}$ & 10 & $\begin{array}{l}\text { Bladder } \\
\text { cancer }\end{array}$ & N/A & No & Gross hematuria \\
\hline Current Case 3 & 78 & M & 9 & $\begin{array}{l}\text { Bladder } \\
\text { cancer }\end{array}$ & No & No & Gross hematuria \\
\hline
\end{tabular}


The final stage of the adenocarcinoma was $\mathrm{T} 2, \mathrm{NO}, \mathrm{M} 0$. The patient died 3 months after surgery from infection-related complications associated with a fistula of the small bowel.

\section{Case 3}

A 38 year-old male with a history of rhabdomyosarcoma of the bladder came to the urology clinic with a 3-week history of progressive episodic lower abdominal pain and hematuria. His surgical history included cystectomy and urinary diversion with an ileal conduit at the age of 5 years. His medical history included chronic nephrolithiasis, urinary tract infections and three episodes of small bowel obstruction managed with extensive enterectomy. A computed tomography (CT) scan and renal ultrasound revealed severe left hydronephrosis and hydroureter without suspicious mass or renal calculi. Cystoscopy showed two masses within the ileal conduit, and biopsy of the tumours showed intestinal tubular adenoma with high-grade dysplasia and focal intramucosal adenocarcinoma. The patient underwent left nephrectomy, right hemicolectomy and complete resection of his ileal conduit. A right hemicolectomy was chosen because it is the standard of care for adenocarcinoma of the distal ileum. A segment of the transverse colon was used to construct the urinary diversion because only $120 \mathrm{~cm}$ of the small bowel remained after the patient's previous operations.

The resected ileal conduit contained a fungating lesion measuring $2.5 \mathrm{~cm}$ in greatest dimension located $0.3 \mathrm{~cm}$ and $2.5 \mathrm{~cm}$, respectively from the ureteral orifices. Histological

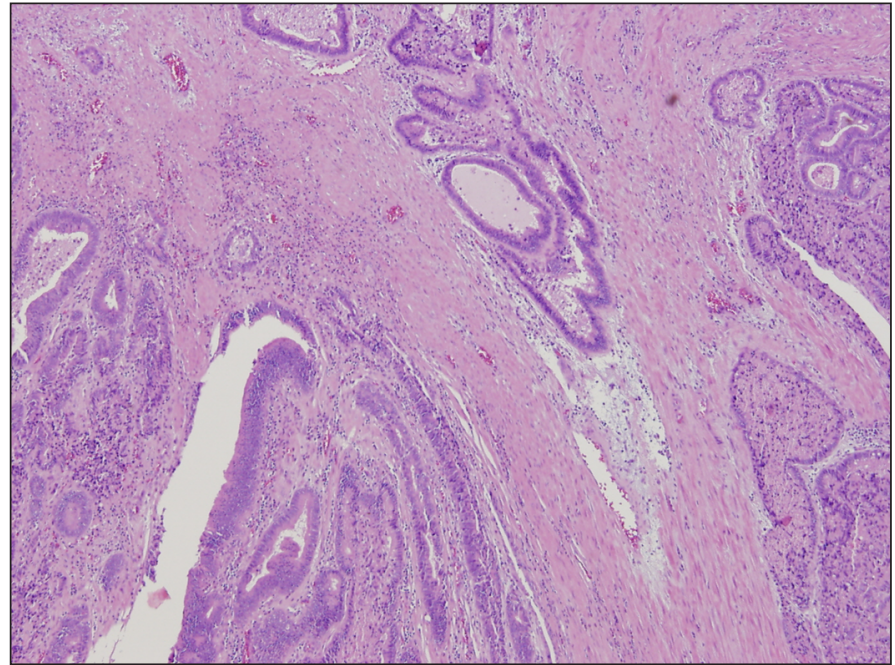

Fig. 3. Histologic examination of resected ileal conduit in case 3 demonstrates moderately-differentiated adenocarcinoma that invades into the muscularis propria. (Hemotoxin \& Eosin, low power magnification).

examination of the tumour revealed moderately-differentiated adenocarcinoma invading into the submucosa and muscularis propria (Fig. 3). Vascular and ureteral margins were free of tumour, and no lymphovascular invasion was identified. Twenty-nine benign lymph nodes were identified, and no evidence of tumour was seen in the left nephrectomy and right hemicolectomy specimens. The final stage of the disease was $\mathrm{T} 2, \mathrm{~N} 0, \mathrm{M} 0$.

\begin{tabular}{|c|c|c|c|c|c|c|}
\hline Author (year) & $\begin{array}{l}\text { Tumour size } \\
(\mathbf{m m})\end{array}$ & $\begin{array}{l}\text { Primary } \\
\text { tumour site }\end{array}$ & $\begin{array}{l}\text { Presence of } \\
\text { metastasis at } \\
\text { presentation }\end{array}$ & Tumour pathology & Treatment & $\begin{array}{l}\text { Outcome and } \\
\text { follow-up }\end{array}$ \\
\hline Lisle et al. $(2000)^{15}$ & $30 \times 30$ & Cecal wall & No & $\begin{array}{l}\text { Adenocarcinoma invading } \\
\text { the pericecal fat }\end{array}$ & Total Resection & $\begin{array}{l}\text { No recurrence } \\
\text { at } 6 \text { months }\end{array}$ \\
\hline $\begin{array}{l}\text { Gazzaniga et al. } \\
(2000)^{19}\end{array}$ & $25 \times 15$ & $\begin{array}{l}\text { Distant from } \\
\text { anastamosis }\end{array}$ & No & $\begin{array}{l}\text { Moderately differentiated, } \\
\text { invading the submucosa }\end{array}$ & Wide local excision & N/A \\
\hline $\begin{array}{l}\text { L'Esperance et al. } \\
(2001)^{16}\end{array}$ & $\mathrm{~N} / \mathrm{A}$ & At anastamosis & Liver & Poorly differentiated & $\begin{array}{l}\text { Total resection, } \\
\text { left nephrectomy, } \\
\text { removal of liver mass }\end{array}$ & $\mathrm{N} / \mathrm{A}$ \\
\hline $\begin{array}{l}\text { Uesugl et al. } \\
(2002)^{14}\end{array}$ & $40 \times 25$ & $\begin{array}{c}\text { Near } \\
\text { anastomosis }\end{array}$ & No & Moderately differentiated & $\begin{array}{l}\text { Total resection, right } \\
\text { nephrectomy }\end{array}$ & $\begin{array}{l}\text { No recurrence } \\
\text { at } 5 \text { months }\end{array}$ \\
\hline $\begin{array}{l}\text { Komai et al. } \\
(2005)^{17}\end{array}$ & $40 \times 60$ & At anastamosis & $\begin{array}{l}\text { Renal pelvis } \\
\text { and calyces }\end{array}$ & Moderately differentiated & $\begin{array}{l}\text { Total resection, } \\
\text { chemotherapy }\end{array}$ & $\begin{array}{c}\text { Deceased at } 17 \\
\text { months from } \\
\text { metastasis }\end{array}$ \\
\hline Ho et al. $(2007)^{18}$ & N/A & N/A & No & Moderately differentiated & $N / A$ & N/A \\
\hline $\begin{array}{l}\text { Ryochi et al. } \\
(2007)^{3}\end{array}$ & $7 \times 7$ & $\begin{array}{l}\text { Distant from } \\
\text { anastamosis }\end{array}$ & No & $\begin{array}{l}\text { Moderately differentiated, } \\
\text { invading mucosa }\end{array}$ & $\begin{array}{l}\text { Endoscopic mucosal } \\
\text { resection due to } \\
\text { small size }\end{array}$ & $\begin{array}{l}\text { No recurrence } \\
\text { at } 15 \text { months }\end{array}$ \\
\hline Case 2 M.M. & $35 \times 25$ & $\begin{array}{l}\text { Distant from } \\
\text { anastamosis }\end{array}$ & No & $\begin{array}{l}\text { Moderately differentiated, } \\
\text { invading submucosa }\end{array}$ & Total resection & $\begin{array}{c}\text { No recurrence } \\
\text { at } 3 \text { years }\end{array}$ \\
\hline Case 3 E.S. & $30 \times 20$ & $\begin{array}{l}\text { Distant from } \\
\text { anastamosis }\end{array}$ & No & $\begin{array}{l}\text { Well differentiated, } \\
\text { invading superficial } \\
\text { muscularis propria }\end{array}$ & Total resection & $\mathrm{N} / \mathrm{A}$ \\
\hline
\end{tabular}


Jian et al.

\section{Discussion}

In case reports and experimental studies, investigators have long hypothesized about the association between the presence of urinary diversion and malignancies in the intestinal tract. The three cases emphasize the diagnostic insights and treatment options associated with adenocarcinoma arising in the urinary diversions and underline the importance of lifelong surveillance in these patients.

In Cases 1 and 2, the patients' adenocarcinomas arose in Indiana pouches. Seven cases have been described in the literature (Table 1, Table 2). ${ }^{3-19}$ The most common initial symptom is gross hematuria. Other signs and symptoms include particulate discharge from the pouch, stones in the pouch, difficulty with catheterization, pouch distention and overflow incontinence. The treatment of choice is complete resection of the Indiana pouch, equivalent to a right hemicolectomy, which is the standard of care for adenocarcinomas arising in the right colon. Case 3 is an example of an adenocarcinoma arising in an ileal conduit. Again, the main presenting symptom was gross hematuria. ${ }^{20-22}$ The length of time between the creation of the ileal conduit and tumour detection as reported in the literature ranged from 14 to 30 years.

\section{Conclusion}

Adenocarcinomas can arise in a variety of circumstances in which intestinal segments are used for urinary diversions. Importantly, latent tumours can arise in a defunctionalized ureterosigmoidostomy, as well as in isolated portions of ileum or colon used for the urinary diversion. Therefore, patients undergoing any type of urinary diversion involving intestinal mucosa should undergo close surveillance following surgery. In patients with colonic reservoirs, consideration should be given to pouchoscopy along with routine colonoscopy when screening for colon cancer. Gross hematuria is the most common symptom and should always be actively investigated. Other signs and symptoms, such as particulate discharge, stones in the pouch, difficulty with catheterization, pouch distention, overflow incontinence, rectal bleeding, changes in bowel habits and abdominal pain should not be overlooked. Detection of localized cancer allows for primary resection of the bowel segment and mesentery, which should be curative.

\footnotetext{
Acknowledgement: The authors would like to thank Dr. Mukul K. Divatia for coordinating retrieval of pathology images.
}

\section{References}

1. Austen M, Käble T. Secondary malignancies in different forms of urinary diversion using isolated gut. J Urol 2004;172:831-8. htrp://dx.doi.org/10.1097/01.ju.0000134890.07434.8e

2. Crissey MM, Steele GD, Gittes RF. Rat model for carcinogenesis in ureterosigmoidostomy. Science 1980;207:1079-80. http://dx.doi.org/10.1126/science.7355272

3. Ryoichi S, Hiroyuki M, Nobuyuki N, et al. Colonic adenocarcinoma in an Indiana pouch successfully treated by endoscopic mucosal resection. Int J Urol 2007;14:661-2. htrp://dx.doi.org/10.1111/i.14422042.2007.01684.x

4. Strachan JR, Woodhouse CR. Malignancy following ureterosigmoidostomy in patients with exstrophy. $\mathrm{Br}$ J Surg 1991;78:1216-8. htrp://dx.doi.org/10.1002/bjs. 1800781021

5. Guy RJ, Handa A, Traill Z, et al. Rectosigmoid carcinoma at previous ureterosigmoidostomy site in a renal transplant recipient: report of a case. Dis Colon Rectum 2001;44:1534-6. http://dx.doi.org/10.1007/ BF02234613

6. Huang A, McPherson GA. Colonic carcinoma after ureterosigmoidostomy. Postgrad Med J 2000;76:579-81. http://dx.doi.org/10.1136/pmi.76.899.579

7. Khan MN, Naqui AH, Lee RE. Carcinoma of sigmoid colon following urinary diversion: a case report and review of literature. World I Surg Oncol 2004;2:20. http://dx.doi.org/10.1186/1477-7819-2-20

8. Recht KA, Belis JA, Kandzari SJ, et al. Ureterosigmoidostomy followed by carcinoma of the colon. Cancer 1979;44:1538-42. http://dx.doi.org/10.1002/1097-0142(197910)44:4<1538::AIDCNCR2820440455>3.0.C0;2-C

9. Sheldon CA, McKinley CR, Hartig PR, et al. Carcinoma at the site of ureterosigmoidostomy. Dis Colon Rectum 1983;26:55-8. http://dx.doi.org/10.1007/BF02554685

10. Sohn M, Fuzesi L, Deutz F, et al. Signet ring cell carcinoma in adenomatous polyp at site of ureterosigmoidostomy 16 years after conversion to ileal conduit. J Urol 1990; 143:805-7.

11. Strachan JR, Rees HC, Cox R, et al. Mucin changes adjacent to carcinoma following ureterosigmoidostomy. Eur Urol 1987;13:419.

12. Weinstein $\mathrm{T}$, Zevin D, Kyzer $\mathrm{S}$, et al. Adenocarcinoma at ureterosigmoidostomy junction in a renal transplant recipient 15 years after conversion to ileal conduit. Clin Nephrol 1995:44:125-7.

13. Shapiro SR, Baez A, Colodny AH, et al. Adenocarcinoma of colon at ureterosigmoidostomy site 14 years after conversion to ileal loop. Urology 1974;3:229-31. http://dx.doi.org/10.1016/500904295(74) $80024-5$

14. Uesugi T, Uno S, Hayashi K. Colonic adenocarcinoma associated with dysplastic lesions in an indiana pouch. J Urol 2002;168:2117. http://dx.doi.org/10.1016/S0022-5347(05)64310-8

15. Lisle D, Cataldo P, Bibawi SE, et al. Colonic adenocarcinoma occurring in an Indiana pouch: report of a case and review of the literature. Dis Colon Rectum 2000;43:864-7. http://dx.doi.org/10.1007/ BF02238028

16. L'Esperance J0, Lakshmanan Y, Trainer AF, et al. Adenocarcinoma in an Indiana pouch after cystectomy for transitional cell carcinoma. J Urol 2001;165:901-2. http://dx.doi.org/10.1016/S0022$5347(05) 66560-3$

17. Komai Y, Kawakita $M$, Shimada 0 , et al. Colonic adenocarcinoma and stones in an Indiana pouch. Int J Urol 2005;12:412-3. htrp://dx.doi.org/10.1111/i.1442-2042.2005.01061.x

18. Ho L, Henderson R, Jadvar H. Adenocarcinoma in an Indiana pouch on PET-CT. Clin Nucl Med 2007;32:578. http://dx.doi.org/10.1097/01.rlu.0000249767.05591.08

19. Gazzaniga MS, Turbow B, Ahlering TE, et al. Adenocarcinoma in an Indiana pouch urinary diversion. J Urol 2000;163:900. htrp://dx.doi.org/10.1016/S0022-5347(05)67832-9

20. $\mathrm{Ng} \mathrm{FC}$, Woodhouse CR, Parkinson MC. Adenocarcinoma in an ileal conduit. Br J Urol 1996;77:321-2. http://dx.doi.org/10.1046/i.1464-410X.1996.91835.x

21. Sakano S, Yoshihiro S, Joko K, et al. Adenocarcinoma developing in an ileal conduit. J Urol 1995; 153:1468. http://dx.doi.org/10.1097/00005392-199501000-00052

22. Tsuboniwa N, Miki T, Kuroda M, et al. Primary adenocarcinoma in an ileal conduit. Int J Urol 1996;3:64-6.

Correspondence: Dr. Seth P. Lerner, Professor of Urology, Beth and Dave Swalm Chair of Urologic Oncology, Scott Department of Urology, Baylor College of Medicine, 6620 Main, Suite 1325, Houston, Texas 77030; fax: 713-798-5553; slerner@bcm.edu

Competing interests: None declared.

This paper has been peer-reviewed. 